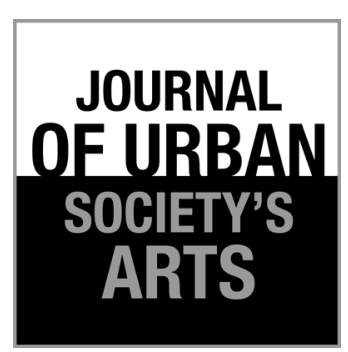

Volume 7 Nomor 2, October 2020: 65-73

\section{The Identity Transformation of Gedog Batik Tuban, East Java}

Fajar Ciptandi

Study Program of Textile Craft and Fashion, Faculty of Creative Industries,

Telkom University

Telekomunikasi Street no. 1, Terusan Buah Batu, Bandung

Email: fajarciptandi@telkomuniversity.ac.id; HP.: +6281221825960

\begin{abstract}
Tuban area in East Java, Indonesia, has a role as one of the ancient international trading ports since the 11 th century. For that role, Tuban has accepted many foreign cultures brought by other nations, such as Tionghoa and Gujarat. Tuban's improvement that involves international relationships influences the forms of tradition and culture shown in Tuban nowadays. It is believed that from those traditions and cultures owned by the people of Tuban, producing cloth is one of the oldest traditions maintained by the people. However, in the current condition, the practice is slowly transforming into modernity. The research aims to explain the change of tradition on Tuban's traditional cloth through a cultural transformation approach to find fundamental ground data and explain external elements that intervene in the tradition. And the new forms result from it.
\end{abstract}

Keywords: batik gedog; Tuban identity

\begin{abstract}
ABSTRAK
Transformasi Identitas Batik Gedog Tuban, Jawa Timur. Kawasan Tuban di Jawa Timur, Indonesia sejak abad ke-11 telah berperan sebagai salah satu pelabuhan perdagangan kuno internasional. Atas perannya tersebut, Tuban mengalami banyak penerimaan kebudayaankebudayaan asing yang dibawa oleh bangsa seperti Tionghoa dan Gujarat. Perkembangan Tuban yang melibatkan hubungan antarbangsa itu secara nyata turut berpengaruh pula terhadap wujud-wujud tradisi dan kebudayaan yang tampak di Tuban saat ini. Diyakini dari sekian banyak tradisi dan kebudayaan yang ada, membuat kain diperkirakan telah dimiliki oleh masyarakat Tuban sejak lama. Namun, pada kondisi saat ini tradisi tersebut perlahanlahan mengalami transformasi ke arah modernitas. Penelitian ini menjelaskan kondisi perubahan yang terjadi pada produk tradisi kain tradisional masyarakat Tuban melalui pendekatan transformasi budaya untuk menemukan data berupa fundamental ground dari tradisi kain tersebut, serta menjelaskan unsur-unsur eksternal apa saja yang telah mengintervensi tradisi tersebut, serta bentuk-bentuk kebaruan apa yang dihasilkannya.

Kata kunci: batik gedog; identitas Tuban
\end{abstract}

\section{Introduction}

Tuban, one of the regencies in East Java, Indonesia, has a long historical narrative. Since around the $11^{\text {th }}$ century, Tuban has played the role as one of the ancient international trading ports connecting the "western" and "eastern" regions of the world from North India, South India, Sailan
(Sri Lanka), Burma, Cambodia, and Champa (Vietnam) (Sedyawati et al, 1992).

Its role as an international port has caused Tuban to accept a lot of foreign cultures outside of its local cultures; therefore, these have influenced the forms of traditions and cultures that have emerged in Tuban up to the present (Nastiti, 2003a). Of the many forms of tradition and culture 
that were born and have developed in Tuban, based on historical sources of the Biluluk II inscription, one of the traditional activities that have been done for a long time by the people of Tuban is making cloth. This activity is estimated to have started since 1319 AD (Achjadi \& Natanegara, 2010). Apart from being one of the important trading commodities, cloth and dyes are also products of daily necessities, and they have special functions, including: to show one's social status, community group identity, used in rituals, and as parts of a life philosophy that represents the important cycle in life, namely: birth, marriage, and death (Ciptandi et al., 2016).

The identity of the traditional fabric of the Tuban people, especially in terms of values and aesthetics, is now experiencing a pull for a shift towards popularity. The design is slowly opening up to no longer follow traditional standards, but rather free and dynamic creations. Objects in the form of traditional products are passed down through generations although it is undeniable that some are slowly starting to lose their traditional values because they are considered in the context of modernity, in which they are no longer relevant (Ciptandi, 2018).

However, there is one thing that has become strength in maintaining this identity. This is because the gedog woven fabric has long been a symbol of the existence of an identity in the form of a civic culture for the people of Tuban. The values contained in the local wisdom of the gedog woven fabric are then considered to represent the values possessed by a group of people in Tuban itself, such as: simple, diligent, hardworking, and creative. This then creates a feeling of pride within the community, who seem to be tied together as parts of the whole group (Panjaitan \& Sundawa, 2016).

Previously, the people of Tuban used fabric for spiritual and philosophical reasons, and now it has shifted to economic needs. In addition, there has also been a shift in the technique and process of making the fabric, in which today more traditional cloth-making craftsmen prefer to order fabrics from suppliers. Another thing has also happened in the design where in the process of dyeing the fabric, it is increasingly rare to find craftsmen who still maintain the coloring process using natural dyes because they think it is impractical even though this affects the quality of the fabric design visually (Ciptandi et al., 2018).

Factors causing this shift are comprised of acculturation, assimilation, and innovation. In addition, changes to the form of tradition can also be due to the community, either consciously or not and both collectively and individually, who start to improvise by making small compositions of the habits within the traditions. The ideas for this improvisation emerged by themselves as a result of the senses' response to the surrounding conditions (Koentjaraningrat, 2002).

Every human being without exception is a designer. There is no one who does not manipulate the environment or objects around them. Humans subjectively give their personal touch to the environment and these objects to gain recognition for themselves, happiness and comfort, or as a way to fulfill their life needs (Norman, 2004).

This condition shows that there have been gaps in the possibility that the tradition has undergone a transformation as a result of the acceptance and assimilation of foreign traditions/ cultures and the influence of the environmental factors that are constantly changing; therefore, these traditions are not static but constantly move to find novelties. In the transformation within the body of a tradition, there are things that need to be truly understood, namely what is the fundamental ground or the basic spirit that forms the tradition owned by the respective tradition, in the form of traditional knowledge of the values and aesthetics that are present in the form of inheritance through generations. In the context of tradition preservation, it is important to maintain this because it functions as a support for the tradition to not experience an identity crisis (Nugraha, 2011).

\section{Research Methodology}

This study is conducted by grouping the data in the forms of text and visual materials. The text data was obtained from the researcher's personal notes, literature in the form of reference books, 
scientific journals, flyers, posters, power point data, interviews, and email correspondence. The visual materials are data that contains explanations in the form of photos, sketches, and product images. To learn more about these aspects of research, a qualitative methodology was used by prioritizing the assessment of the five senses accurately to see cultures that tend to be dynamic and change over time. In this approach, the researcher became the center in collecting data, following cultural assumptions, and following data. In other words, qualitative cultural research is more flexible, nonfixed, reflective, and imaginative.

Another methodology was needed in the research process, namely the oral tradition. This method took the forms of testimonies that are conveyed orally and transmitted verbally through generations. These oral testimonies were documented through a long process of in-depth interviews with traditional figures or actors who have gone through a certain period of time. This method was used to process the data on traditions whose written sources are difficult to find, but are actually developing in the community.

\section{Discussion}

Traditional products have a very important role in maintaining and preserving the existence of traditions. In the current situation, some people still believe that efforts to preserve traditions need to be carried out with a conservative approach, that is, all elements contained in the tradition must be preserved without being subject to any changes.

\begin{tabular}{|c|c|}
\hline Traditional Form & Traditional Innovation Form \\
\hline $\begin{array}{c}\text { AESTHETICS } \\
\text { (Meanings: Myths, symbols, spiritual, } \\
\text { cosmology, art, history, and rituals) }\end{array}$ & $\begin{array}{c}\text { LIFESTYLE } \\
\text { (created by market and consumers' } \\
\text { tastes) }\end{array}$ \\
\hline $\begin{array}{c}\text { TRADITIONAL DESIGN } \\
\text { (Forms, functions, structures, sizes, } \\
\text { visual aesthetics) }\end{array}$ & $\begin{array}{l}\text { NEW DESIGNS } \\
\text { (Develops toward forms, functions, } \\
\text { structures, sizes, and new visual } \\
\text { aesthetics based on current trends) }\end{array}$ \\
\hline $\begin{array}{c}\text { TECHNIQUE, PROCESS, } \\
\text { MATERIALS }\end{array}$ & $\begin{array}{l}\text { Technology and development of } \\
\text { production models }\end{array}$ \\
\hline $\begin{array}{c}\text { HUMANS } \\
\begin{array}{c}\text { (Society, mentality, social environment, } \\
\text { and motivations) }\end{array}\end{array}$ & $\begin{array}{l}\text { Advancement of humans' quality and } \\
\text { social system }\end{array}$ \\
\hline Conservative & Global-Local \\
\hline
\end{tabular}

Figure 1. The shifting of traditional conditions form and innovation form in the Tuban's unique gedog batik cloth. Source: Ciptandi, 2018.
Society is slowly starting to open its mind towards a more dynamic direction in dealing with traditional issues. There are also those who are moderate by arguing that all forms of changes are considered necessities. If the body of the tradition undergoes a change, it is normal as long as the fundamental ground of the tradition is maintained. Furthermore, there are also those who take a radical stance by assuming that a tradition can be transformed into whatever new form it wants due to various influences from both internal and external factors as long as its identity and characteristics are not lost (Ciptandi et al., 2018).

In this regard, it is necessary to see how changes in the order of the tradition in the local community of Tuban occur as a response to the adjustment of a growing trend, and even the form of the woven cloth unique to Tuban will continue to experience shifts.

In the current condition, some of the elements that form the identity of the traditional Tuban fabrics are still being maintained, but some have undergone a transformation to new forms as a result of their response to trends.

\section{The Shift of Identity in the Dimensions and Functions of Fabric}

Traditional Tuban fabric designs are made to adapt to the usage of the fabric. The main usages of fabric for Tuban people are as a sayut (shawl cloth wrapped around the shoulder to carry goods) and jarit (a cloth covering the body by wrapping it around from the upper chest to the ankles). Until today, the design of sayut and jarit has never changed in terms of shape and size. The shift occurs in the choice of material by not using gedog batik woven fabric for sayut and jarit, but using printed-batik fabric. This is because the weaving

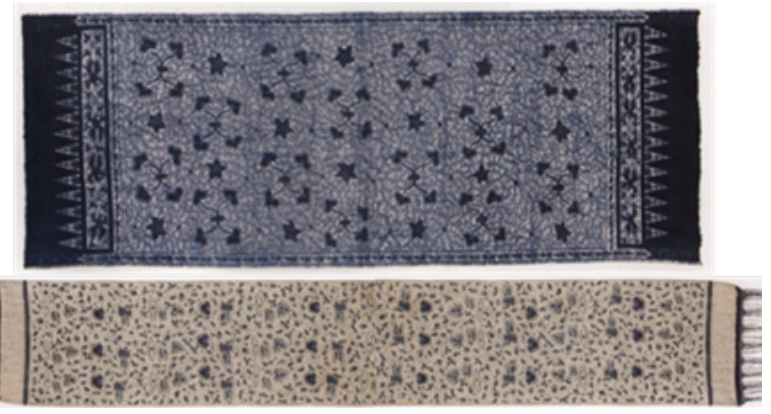

Figure 2. Design of Jarit (top) and Sayut (bottom) Unique to Tuban. Source: Heringa, 2010. 
of gedog sayut and gedog jarit are very complicated to work with and the price of these fabrics is relatively expensive (Ciptandi et al., 2016).

The habit of wearing sayut and jarit for women in Tuban is still there although only for a few of them, mostly belonging to older generation. Most middle-aged women in Tuban still wear these two types of cloth when going to the fields or a market. Meanwhile, very few young women were these. They consciously say that they prefer to dress casually because it is more practical and fashionable (Heringa, 2010).

\section{The Shift of the Visual Elements of Fabric: Pattern, Composition, and Color}

The appearance of Tuban Gedog batik has distinctive characteristics with rougher pattern lines and is far from being neat. The composition of the pattern does not have a special pattern. The appearance of the Tuban batik has its own charm precisely because of the roughness of the material it uses. In addition, the faint color from the coloring using natural dyes also gives an old impression; therefore, it is in great demand by collectors and foreign tourists. Tuban gedog batik mostly has a patterned composition but not precise (Djoemena, 2000).

The batik patterns created by the community on the fabric are created due to the stimuli in the form of objects from the surrounding environment, responded by humans' five senses and then influenced by their knowledge and insights about cosmological concepts, behavior and habits, beliefs; and they are represented in a

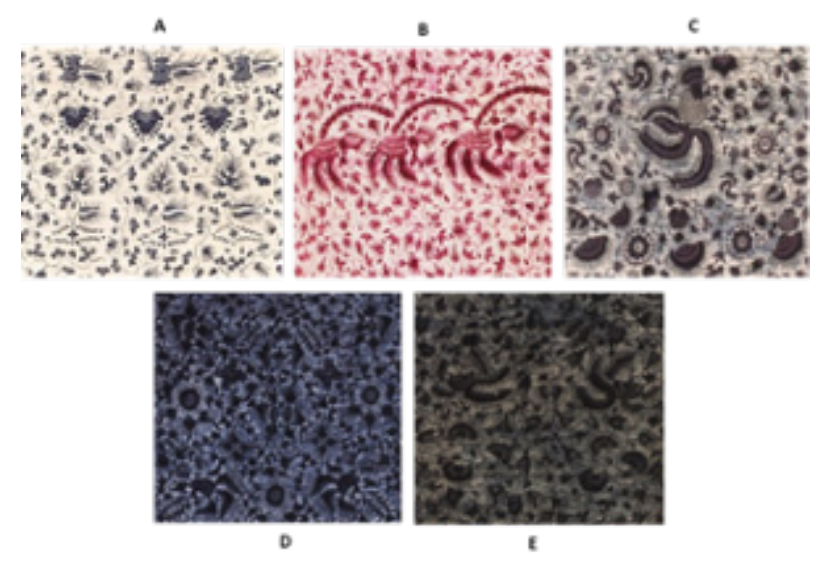

Figure 3. (A) Putihan, (B) Bangrod, (C) Pipitan, (D) Biron, dan (E) Irengan. Source: Heringa, 2010. visual display. What inspires the decorative styles they create tends to be close to what they find on a daily basis in their environment, and some are influenced by the acculturation of foreign cultures that have entered Indonesia and have had influences on the visual styling of these patterns (Gillow, 1995).

The patterns of Tuban gedog batik depict objects around the Tuban people. Some of these traditional patterns have originally survived until now due to the existence of information through oral traditions which continues without breaking off (Heringa, 2010). Meanwhile, some others have undergone modifications to create various pattern creations while still taking elements of traditional patterns as their inspiration. In this case, there is no rejection from the Tuban people themselves, and this as a representation that they are an open minded society that are open to changes (Ciptandi, 2018).

Another design element is fabric coloring. Traditionally, fabric is dyed using natural dyes and produce colors that represent the cosmological concept of the Tuban people, the Cycle of Life. This concept was poured into the aesthetics of colors, namely: putihan, which is white cloth with dark blue or black patterns, bangrod, which is red cloth, pipitan, brown cloth with remekan base (cracked effect), biron, blue cloth with dark blue or black pattern, and irengan, which is black cloth (Ciptandi \& Sachari, 2018).

In its development, gedog batik of Tuban has begun to use synthetic dyes since around the end of the $19^{\text {th }}$ century. These synthetic dyes have begun to change some of the habits of the people in coloring the fabric, especially for the batik community in Tuban. Up to the present, the use of synthetic dyes is increasingly popular. This is not only for the reasons of brighter and more diverse colors, but also for reasons of effectiveness and the fact that it opens opportunities for the middle market segment (Achjadi \& Natanegara, 2010).

However, although synthetic dyes use is growing rapidly, the use of natural dyes also in fact still has a 'place' even though the amount is decreasing. There is a motivation among some 
batik artisans in Tuban to develop batik not only for the economic motivation, but also for the sustainability of traditions and the environment.

Most of the artisans who still create or produce fabric have switched to using synthetic dyes and found market opportunities that can keep their businesses running. As of today, there is no threat of conflict between traditional batik and modern batik creations. The two actually complement each other to form a new face for the cloth tradition compared with the beginning of the existence of tradition.

\section{The Shift of the Visual Elements of Fabric: Pattern, Composition, and Color}

The raw material for textile fibers that grows in Tuban is a variety of Gossypium herbaceum or better known as Javanese cotton, which is lower in type than mori cotton (which is the raw material for making mori cotton fabric for batik). This cotton yields less when harvested and tends to be coarser. However, this type of cotton is still used by local people as the main raw material for making textiles for clothing (Simanjuntak \& Santosa, 2014).

This Javanese cotton consists of two types, namely white cotton (lawed) and brown cotton (lawa-which means bat, because its brown color resembles bat's fur). This cotton is the only raw material used by the people of Tuban to make cloth. Apart from this cotton fiber, in 2014 the people of Tuban received training in weaving using Bombyx mori silk fiber, but this was unsuccessful. In contrast to the behavior of batik artisans who can be more open minded to changes in batik patterns, gedog weavers are still conservative and have not been able to leave the traditional behavior (Ciptandi, 2018).
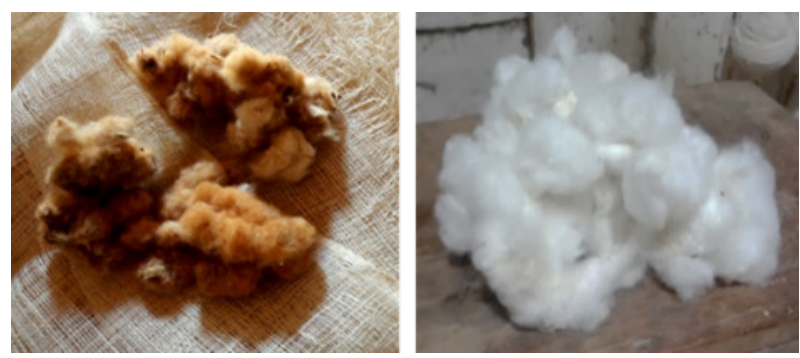

Figure 4. Brown cotton fiber (lawa) and white cotton fiber (lawed). Source: Author, 2015.
The availability of cotton for the sustainability of the traditional gedog batik cloth tradition in Tuban is important because it contributes to the continuation of the activities of spinning yarn and weaving fabric. Cotton and traditional fabric in Tuban have a strong culture that dates back to "ancient" times. People used to grow their own cotton fiber, spinning and weaving it into sheets of fabric. Therefore, maintaining the culture owned by the community is actually the right way to preserve the tradition of making such fabric.

The fact about the current condition is that the cotton plantation areas are getting harder to find. Most of the wild cotton land that was once abundant has now been replaced by the constructions of PT Semen Indonesia. This condition has caused the changes in people's behavior as now they are forced to order cotton fiber from other areas (Ciptandi, 2018).

This change opens the possibility of losing the old culture that will be replaced by a new culture. Even though there is no right or wrong answer to any culture, in the context of maintaining a traditional identity, the culture which is "inherited" from the original tradition can be preserved as a form of inheritance from the tradition itself.

\section{The Shift in Fabric Production Techniques}

The making of traditional Tuban fabric requires a complicated process using gedog weaving technique to produce sheets of fabric and using the batik technique to decorate the fabric with patterns and colors.

For the people of Tuban, weaving is not only an activity to make fabric, but also has a philosophical meaning about life. In weaving, there are generally two types of threads that cross each other to form a braid, namely: vertical yarn or better known by the Tuban people as lungsi and horizontal yarn or better known as pakan. The working principle of weaving is to insert the pakan from the east to the west. The direction of this yarn, from east to west, has a philosophy as it represents the direction of the sun that rises in the east and sets in the west. This is also how 
life begins. The lungsi is interpreted as the 'path of men' and the pakan as the 'path of women'. It is stated by Achjadi that a piece of woven fabric means that every men and women are in a marriage bond (Achjadi \& Natanegara, 2010).

Weaving activities in Tuban is slowly decreasing. Only a handful of the Tuban People are still willing to do it, and most of them are elderly women. The main reason is because there is a growing perception that weaving is not popular, apart from the complicated process that takes a long time to complete each sheet of cloth.

Traditions can survive if there are regenerations to continue certain activities over and over again. Even if there are changes, tradition at least can be maintained by developing new values while still carrying the traditional identity as its inspiration. The characteristic values contained in this tradition are expected to be able to stick to society and mitigate the negative impacts of the powerful globalization. (Harmawati et al., 2016).

Like the weaving gedog tradition that exists in Tuban, it does not have values that are contrary to the rules and philosophy of life of the local community. However, its complex process can be a strong reason why traditions are abandoned and replaced by new traditions that are able to produce similar products without being constrained by complicatedness and long lead time.

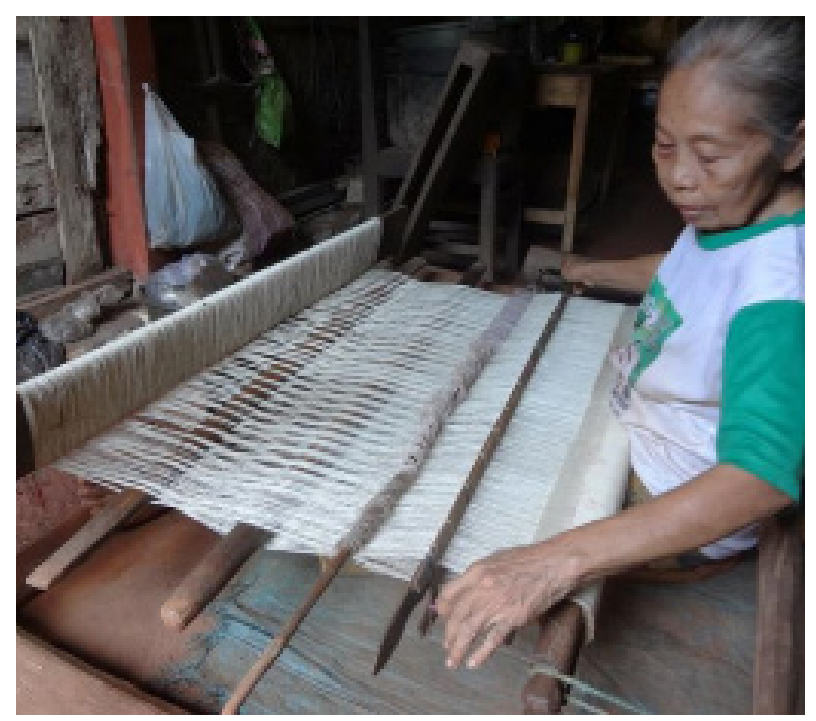

Figure 5. Gedog weaving activities by a woman in Tuban. Source: Author, 2015.
The last process is to decorate plain woven fabric with distinctive ornaments using batik techniques, both hand-drawn and printed. Observations on the batik making carried out by batik artisans in Tuban showed that its process are not much different from batik making in other areas Tuban; only the terms in the process are different in each region.

The activity of making batik done by women in Tuban, similar to weaving, is not their main job. This activity is a kind of leisure activity when they are not farming, waiting for the planting season, or when they have just finished harvesting their crops. However, nowadays there are many women in Tuban who choose not to farm and become batik artisans. Some of the women work for batik entrepreneurs from morning to evening every day while some others only take the fabric and do the batik at home (Ciptandi et al., 2016).

Up to the present, making batik is often found in the Tuban and done both by young women and elderly woman.

\section{The Shift in the Condition of Gedog Batik Artisan Community in Tuban}

For a long time, cloth for the people of Tuban has not only functioned as clothing, but also had a connection with social values in society. The function of cloth is related to its relationship to social conditions that are comprised of the following:

a. Cloth as a commercial commodity that they are usually exchanged with various daily necessities through the barter system. For the people of Tuban in particular, traditional fabric has had a high enough selling value and its exchange value for money is quite stable. Regarding the barter system, the evidence for this shows that it started in the advanced food gathering economies. At this level, the community begins to recognize a surplus, and the excess production will be distributed through exchanges, either through the barter system or using money (Nastiti, 2003).

b. Apart from being primary items, cloth can also be used to show one's social status. Up until 
the mid-1980s, traditional Tuban cloth had been considered by traditional communities to have a role as an indicator of identity and social status of certain communities. The long shawl or often referred to as sayut worn by Tuban women indicated the age group of a person wearing it and could indicate whether she was an unmarried woman, married woman, or elderly woman. On the other hand, the jarit cloth used by Tuban women could also show their identity in terms of which village they came from, whether it is located to the east, south, west, or north of the market location (Achjadi \& Natanegara, 2010).

Figure 6 shows three Tuban women wearing the original batik jarit made by the Tuban community. The jarit worn by the woman number 1 indicates that she comes from a high social status family. In addition, the woman is wearing a dark blue camisole top while carrying her child behind her using a printed batik cloth. The second woman (number 2) comes from a family with low a social status; she wears gedog woven fabric to wrap her body and protect her chest using only one piece of cloth wrapped around her body. The young woman

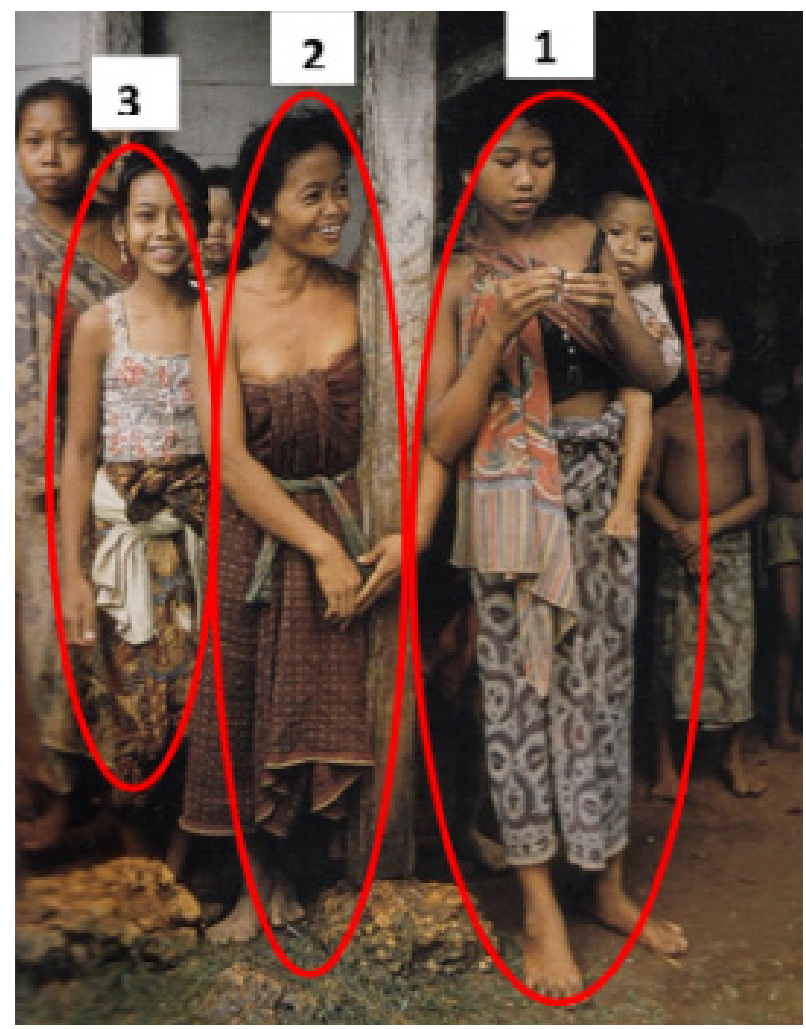

Figure 6. Cloth as an indicator of identity and social status in a community. Source: Heringa, 2010. (number 3) is wearing a printed camisole with floral pattern and a skirt from printed batik cloth. Her outfit shows her status as a member of a farm labor family, who does not own their own agricultural land. In addition, the white cloth tied around her waist shows that she just had her first menstruation (Heringa, 2010).

The sight of women in Tuban wearing sayut and jarit following the rules as explained earlier is becoming increasingly rare nowadays. Although there are women in Tuban who still wear them, usually they are no longer tied to the social function of the cloth. The Tuban women wearing sayut are mostly farmers going to the fields while carrying baskets filled with food supplies or equipment for farming. In addition, some women in Tuban also still use sayut when going to the market to carry their goods or groceries. The sayut they use are not always made of traditional fabric; some of the women have switched to using printing fabric.

Nowadays, fewer women are wearing jarit, and most of the women in Tuban today prefer to appear without jarit because this cloth is considered impractical and old fashioned, and it is especially true for young women. This shows that the cloth has undergone a shift in the level of its values. Previously, using or wearing sayut and jarit was considered a way of dressing that is appropriate and represents Tuban, but now it is increasingly being abandoned for reasons that are in accordance with the context of modernity.

From all the descriptions of the conditions regarding the identity of traditional cloth and its current shift, it seems that: 1) Kerek community, who previously pictured the characteristics of a rural community, now appears to be shifting towards the characteristics of suburban communities, one of which is triggered by their environmental condition, which their close proximity to industrial areas, 2) spiritual practices in the form of rituals and traditional ceremonies no longer have the power to bind the Kerek community due to the diminishing level of belief and appreciation of the Kerek community towards this belief, and 3) the wide opportunities to receive the flow of information and technology quickly has given impacts on people's mindsets, motivations, and ways of making decisions. 


\section{Conclusion}

The identity of the values and aesthetics of the Tuban traditional fabric has shown a symptom of transformation by leaving some of its traditional forms and adapting to the development of trends and modernity. In fact, there has been a decrease in the role of cloth in the condition of current society. Cloth is no longer considered too important because now the Tuban community's appreciation of traditional values is fading. Few people in Tuban still understand the philosophy behind this tradition. Although there are people who continue to wear certain types of cloth for traditional celebrations and ceremonies, it is only limited to maintain the custom that has been passed through generations without having any awareness of the meaning of the philosophy.

This is based on the concept of tradition transformation, which may occur in that the people of Tuban are now considering their own customs no longer relevant and in line with their needs and motivation for life: therefore, the community feels no importance to preserve it.

This occurs especially to gedog batik for sayut and jarit since the meanings they contain are not considered sacred from the beginning. Although they are believed to be able to counter misfortunes or parts of customary needs (such as at birth, death or wedding ceremonies), the usage of these cloth types as garments is not regulated by binding and compelling rules. There is no rule stating that if a woman is not wearing them according to the correct manner, the woman will be punished accordingly.

For some women the use of this cloth is solely as a garment, and the way it is used has been taught from generation to generation. Based on this characteristic, changes in the use of fabric for Tuban women are very likely to happen because there are no rules that bind them. It is proven by the current condition that most women in Tuban are starting to freely choose their clothes and gradually abandon the use of sayut and jarit.

The existence of nontraditional batik for some people in Tuban is considered a threat to the preservation of local traditions. However, if it is viewed from the common efforts to maintain the existence of the tradition of making batik for the people of Tuban, this can be a positive development. If they continue to adhere to traditional customs where weaving and making/ drawing batik require a lot of time with a high level of complexity, it is feared that they will not be able to cover the economic needs of the local community. This of course can gradually become a threat that causes the tradition to become extinct. Therefore, the presence of artisans who stayed in this segment actually helps to maintain batik and woven fabric to remain 'flourishing' in Tuban. Meanwhile, others can remain focused on their conservation efforts to make sure their traditional values are not forgotten.

To date, there are no threat of conflict between the context of tradition and modernity. The two actually complement each other to form a new face for fabric tradition, and this novelty can be compared to the early fabric tradition that existed within Tuban community. This shows that there is a way of introducing and accepting foreign traditions, so that the acculturation and enculturation process between indigenous Tuban traditions and foreign traditions can work successfully. The adaptation process takes place perfectly for the acculturation and enculturation processes to occur without the need for conflicts. Therefore, the face of identity represented by the tradition of gedog batik in Tuban is now communally recognized as the new identity of Tuban people. This is also one of the characteristics that represent the views of the Tuban people, who are open to changes.

\section{References}

Achjadi, J. K., \& Natanegara, E. A. (2010). Tenun Gedog: The Hand-loomed Fabrics of Tuban, East. Java, Media Indonesia Publishing.

Ciptandi, F. (2018). Transformation on Design of Gedog Weaving and Traditional 'Tuban' Batik Decoration Through Visual Characteristic Experiment. Institut Teknologi Bandung.

Ciptandi, F., \& Sachari, A. (2018). "Mancapat" Concept on Traditional Cloth Cosmology of Tuban Community, East Java, Indonesia. 
Advanced Science Letters, 24(4), 2243-2246. https://doi.org/10.1166/asl.2018.10926

Ciptandi, F., Sachari, A., \& Haldani, A. (2016).

Fungsi dan Nilai pada Kain Batik Tulis Gedhog Khas Masyarakat di Kecamatan Kerek, Kabupaten Tuban, Jawa Timur. Panggung, 26(3).

Ciptandi, F., Sachari, A., Haldani, A., \& Sunarya, Y. Y. (2018). Identity Shift On Traditional Clothes For Women Tuban, East Java, Indonesia. Proceedings of the 4th Bandung Creative Movement International Conference on Creative Industries 2017 (4th BCM 2017).

Djoemena, N. S. (2000). Lurik: Garis-garis Bertuah. Djambatan.

Gillow, J. (1995). Traditional Indonesian Textile. Thames and Hudson Ltd.

Harmawati, Y., Abdulkarim, A., \& -, R. (2016). Nilai Budaya Tradisi Dieng Culture Festival sebagai Kearifan Lokal untuk Membangun Karakter Bangsa. Journal of Urban Society's Arts, 3(2), 82-95.

Heringa, R. (2010). Ninik Towok's Spinning Wheel: Cloth and the Cycle of Life in Tuban-East Java. Fowler Museum.

Koentjaraningrat. (2002). Pengantar Ilmu Antropologi. PT. Rineka Cipta, IKAPI.
Nastiti, T. S. (2003a). Pasar Di Jawa Masa Mataram Kuno Abad VIII - XI Masehi. PT Kiblat Buku Utama.

Nastiti, T. S. (2003b). Pasar Di Jawa Masa Mataram Kuno Abad VIII - XI Masehi. PT Kiblat Buku Utama.

Norman, A. D. (2004). Emotional Design, Why We Love (or Hate) Every Things. Basic Books.

Nugraha, A. (2011). Transforming Tradition: A Method for Maintaining Tradition in a Craft and Design Context. Doctoral Disertation Aalto University, School of Arts, Design and Architecture.

Panjaitan, L. M., \& Sundawa, D. (2016). Pelestarian Nilai-Nilai Civic Culture dalam Memperkuat Identitas Budaya Masyarakat: Makna Simbolik Ulos dalam Pelaksanaan Perkawinan Masyarakat Batak Toba di Sitorang. Journal of Urban Society's Arts, 3(2), 64-72. https:// doi.org/10.24821/jousa.v3i2.1481

Sedyawati, E., Manus W. P. B., Raharjo, S. (1992). Tuban: Kota Pelabuhan di Jalan Sutera, Departemen Pendidikan dan Kebudayaan, Direktorat Sejarah dan Nilai Tradisional (I. Jakarta (ed.)). Proyek Inventarisasi dan Dokumentasi Sejarah Nasional.

Simanjuntak, H., \& Santosa, B. R. (2014). The History of Java. Penerbit 